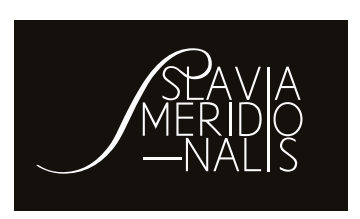

\title{
Citation:
}

Article No.: 2161

Азманова-Рударска, Е. (2020). Християнство, мистицизъм, безверие: Иван Грозев и Николай Райнов. Slavia Meridionalis, 20, Article 2161. https://doi.org/10.11649/sm.2161

Azmanova-Rudarska, E. (2020). Khristiianstvo, mistitsizŭm, bezverie: Ivan Grozev i Nikolaŭ Raĭnov. Slavia Meridionalis, 20, Article 2161. https://doi.org/10.11649/sm.2161

\section{Елена Азманова-Рударска}

Югозападен университет „Неофит Рилски“, Благоевград https://orcid.org/0000-0001-6757-9887

\section{Християнство, мистицизъм, безверие: Иван Грозев и Николай Райнов ${ }^{1}$}

Цел на настоящата статия е да опише една специфична трансформация на религиозните нагласи на българските интелектуалци, протекла през първата половина на XX век и преминаваща от християнство през мистицизъм към новите условия на атеизъм след 1944 година. В основата на наблюденията са положени отношенията между Иван Грозев и Николай Райнов, като представителни за разглежданите културни процеси. Възприемани като двамата най-последователни и най-задълбочени автори мистици, техните разсъждения за вярата, безверието, мистицизма, изкуството и творчеството утвърждават разширената представа за въздействието на ирационалното върху творческия акт. В същото време те запазват много близки отношения и изразяваните от тях крайни при-

1 В тази статия са използвани части от книгата „Иван Грозев в българската литература“ (Азманова-Рударска, 2018), като са редактирани и допълнени.

This work was supported by the Bulgarian Ministry of Education and Sciences.

Competing interests: no competing interests have been declared.

Publisher: Institute of Slavic Studies, Polish Academy of Sciences.

This is an Open Access article distributed under the terms of the Creative Commons Attribution 3.0 PL License (creativecommons.org/licenses/by/3.0/pl/), which permits redistribution, commercial and non-commercial, provided that the article is properly cited. @ The Author(s) 2020. 
страстия (от приемане до отричане) също повлияват конструктивно или деструктивно творческата инвенция. Тяхното поведение в личностен и обществен план е част от литературните и религиозно-мистичните диалози сред интелигенцията през разглеждания период. Нещо повече, отношенията между двамата са умален модел на културни взаимоотношения както преди, така и след 1944 година.

Още в началото на творческия си път те са силно привлечени от християнството. И двамата имат своите различни пътища към религията - и докато Иван Грозев усвоява християнството през книжовното наследство и това се оказва началото на едно симбиотично начало, в което ще се разбъркат християнство и мистицизъм, то Николай Райнов става семинарист и се запознава в дълбочина и с прецизност с ортодоксалните догми.

На въпроса на своя приятел Жорж Нурижан „Кога почувствахте нужда да се вглъбявате в мистични проблеми?“ Иван Грозев отговаря:

Още от най-ранна възраст. Бях дълбоко религиозен и обичах да чета Апокалипсиса, на ръка ми попадна „Пътешественик“ от Иван Бънян ${ }^{2}$, а по-късно и „Ходене по митарствата“. Тези две книги ме разтърсиха и определиха моя път по-нататък в живота - да диря Истината на всяка цена. В гимназията нищо не можах да разбера, в университета още по-малко, макар че се залових с ревност да изучавам психология и философия - науката ме разочароваше, философията ме оставяше незадоволен. Тогава се залових с изучаване на спиритическите феномени, но и там намерих хаос от неясни догадки и мъгляви хипотези... Най-после стигнах до Теософията - Мъдростта на Боговете, която чрез несъмнен вътрешен опит, чрез вътрешно прозрение (интуицията) ни води светкавичното откровение на абсолютната Истина (Нурижан, 1940, с. 44).

Така именно протестантската книжнина се оказва информативният пласт, а не каноничната ортодоксална литература. Книгата на Джон Бъниан, английски протестантски писател, е едно от разпространяващите

${ }^{2}$ Иван Бънян - Джон Бъниан (1628-1688), английски протестантски писател. Автор е на около 30 произведения, от които най-известно е „Проповедникът“ (Бънян, 1866). Тази книга на английския проповедник се радва на популярност сред българските читатели - шест преводни издания в периода 1866-1939 г. и шест преводни издания в периода 1991-2010 г. (Головински, 1999).

${ }_{3}$ Вероятно става въпрос за популярния апокриф „Митарствата на блажена Теодора“, силно разпространен по време на Възраждането. Има единадесет издания в периода 1843-1929 г., като пет от тях са в периода 1843-1874 г. 
се безпрепятствено четива, които увличат и дори запознати с религията не правят съществена разлика между протестантските и ортодоксалните съчинения. Това присъствие безспорно говори за битуване на идеите на Западна Европа в България, но и опосредства осмислянето на нови идеи, свързани с въпроса за националната идентичност. Нейното влияние върху образованието, ценностните утвърждавания и широката популярна просветителска роля са безспорни, заради което са проведени редица изследвания (по-подробно виж Илчев \& Митев, 2003; Куличев, 2008; Пилева, 2018), което не е предмет на настоящето изследване. Според Ев. Джевиецка протестантството е един от каналите за възприемане на Западната култура в България и отнася това проникване към XIX век, като определя мисионерите като „неопротестанти“ (Джевиецка, 2017, с. 2). Както основателно отбелязва в своето задълбочено изследване, „българските писатели са съгласни, че „протестантите“не разбират националния им интерес“ (Джевиецка, 2017, с. 7), но Грозев ползва протестантската литература за усвояване на етични норми, морални проблематики и дори екзистенциални въпроси. Съчетанието й с апокрифната книжнина е предпоставка за все по-увеличаващия се интерес към мистичното.

Николай Райнов завършва Духовната семинария през 1908 година (Цанев, 1982, с. 184). В творчеството си много последователно застъпва библейски мотиви за светци, отшелници и пророци. Пресъздава образа на Исус Христос в романа „Между пустинята и живота“, а „богомилските легенди“ и като заглавие на книга, и като тематика са представителни за творчеството му. Едновременно със следването на ортодоксалните модели, в художествените си интерпретации вплита и немалко отклонения от християнската догма. Заради тези си прегрешения и най-вече заради романа си „Между пустинята и живота“ е отлъчен от църквата. „Най-голяма благодарност дължа на семинарията, дето ме научиха да мисля, да мълча, да почитам, да съзерцавам и да търся нещо по-горно от човека“ (Добринов, 1922). Макар съвременните изследователи да отделят внимание на мистичните увлечения на Райнов (Сугарев, 2007; Трендафилов, 1991), малка част от тях провиждат връзката между източноправославието и езотеричните идеи (Георгиева, 2008; Джевиецка, 2010; Димитрова, 2008; Стойчева, 2007; Шват-Гълъбова, 2010). Според Джевиецка „причините за идейния синкретизъм“ се съдържат в „увлечението по окултизма, кабалата и изобщо гностическите традиции“" (Джевиецка, 2010, 
с. 151), а романът на Райнов „Между пустинята и живота“ се държи като апокриф (Джевиецка, 2010, с. 153).

Н. Райнов е автор и на няколко статии и брошури, свързани с мистицизма. В една своя реч във Военния клуб в София през 1919 г. той коментира отношението мистика -неверие по следния начин:

Ако погледнем отношението на съвременния човек към вечните въпроси, ще отбележим, че има два вида хора. Едните могат да се нарекат мистици, а другите безверници... [...] Кой е безверник? Кой е мистик? Де да ги търсим? По що да ги открием? Слава Богу, няма защо да отиваме отвън облаците. Безверникът е тук. Мистикът - също. Всеки от нас е или мистик или безверник [...] (Н. Райнов, 1925b, с. 11).

Това разбиране усложнява процесите на трансформация на религиозните възгледи у Райнов. Крайната диференциация „наличие-липса“ всъщност се отразява и по отношение на православието, и по отношение на вярванията изобщо у Райнов. От изключително значение за творческия облик на произведенията на мистична тематика както у Грозев, така и у Райнов е апокрифният текст, който бива ясно осъзнат и от двамата, но употребяван по различен начин. Докато за Грозев този текст му осигурява търсената национална идентификация (най-вече през богомилството), то за Райнов това е преднамерено търсен похват на оразличаване (дори чрез богомилството). Така, докато Грозев и в следващите си „митарства“ в различни религиозно-мистични учения ще търси уподобяването и припознаването, то Райнов ще се стреми да се откроява. Тези две поведения залагат две противоположни същности - утвърждаващата и отрицаващата.

За начало на приятелството между Николай Райнов и Иван Грозев се приема времето на публикуване на „Богомилски легенди“ (1912) на Райнов. „Седнали с чичо Грозев до свитата в леглото тетка Мица, ние разглеждахме „Богомилски легенди“ - тая книга-чудо, която тетка прелистваше с благоговение, а Грозев тълкуваше по теософски“ - разказва племенникът на Иван Грозев, Михаил Грозев - Кремен ${ }^{4}$.

Той се спираше на цитатите, печатани в долния край на всяко заглавие и казваше с премрежени очи: „Аноним непременно е теософ. Вижте латинската

4 Това са спомени в ръкописа „Неизвестната“ - части от емблематичната книга на М. Кремен „Романът на Яворов“. Тази глава остава неиздадена вероятно заради скандалните си моменти на спомени за други писатели и трети лица. В архивите на М. Кремен в НБКМ и в ЦДА се съхраняват ръкописните записки и бележки, в които има и спомени за трети лица. Повече виж: БИА - НБКМ, ф. 651, а.е. 7, л. 3471. 
извадка от „Ритуала на Черната магия“ на дамаскинеца Мелкиор. Това пък е цитат от Лао Тзай: „Кръгът - ето движението на Тао“ или „Той пи четири пъти от чашата на Трите Деня“. Мици, виж тук от Зенд Авеста: „Той яде Огън и пие Светлина“. Тоз човек е чел „Книгата на Тота за звездите“, а и Салустий, и Бхагавад гита... Чудо ти казвам!“. „Непременно е от нашите! - се обади тетка Мица, посягайки към вълшебната книга. - Трябва да го открием и да го поканим у дома! (НА - НБКМ, ф. 651, а.е. 7, л. 3494).

Така започва познанството на сем. Грозеви и Николай Райнов. В основата на това сближаване е една от най-популярните жени в София в края на XIX и началото на XX век - Мария Гюлова ${ }^{5}$, съпругата на Иван Грозев. В нея са влюбени известни личности от средите на софийската интелигенция като Кирил Христов, Николай Райнов, Софроний Ников, Дякон Евстати (Черният войвода). С Пейо К. Яворов пък има романтично-моралистична закачка - „неизвестната В“ на Яворов всъщност е Мария Гюлова-Грозева 6 .

Мария Гюлова е красива, интелигентна, дръзка, остроумна, находчива. Дори племенникът ѝ Михаил Кремен не крие възхищението си:

Толкова необикновена ми се стори тя, тъй ангелски неземна [...]. Бях поразен. Веднага се влюбих [...]. И с още замъгления поглед на подрастващо момче търсех да разбера кое е пленителното у нея. Тя беше уж скромна, а кокетничеше, примамваше като нимфа, но изглеждаше недостъпна (БИА - НБКМ, ф. 651, а.е. 7 , л. 3474$)$.

Няма да го крия: бях влюбен, по детски разбира се - не като похотливия македонски войвода дякон Евстати, не като лицемерния теософ Софрони Ников и Сатанаила - автор на „Богомилски легенди“, не и като влюбчивия поет Кирил Христов (БИА - НБКМ, ф. 651, а.е. 7, л. 3474).

Това синтезирано описание представя образите на интелектуалците от онова време много земно, приближено. Те също се оказват хора, със своите страсти, пристрастия и произтичащите от това напрежения и субективности, отразили се върху взаимоотношенията им, най-вече от тяхна страна към Ив. Грозев - той остава в „списъците“ на тези хора като „преди“, „покрай“ и „встрани“, но никога изцяло признат творец. „Грешката“ на Иван Грозев е, че е обичан от и женен за красива, умна и недостъпна жена.

5 За нея по-подробно виж в Азманова-Рударска, 2018.

6 Отношенията между Яворов и Мария Гюлова са проследени по-подробно в Азманова-Рударска, 2018. Също и в: Памуков, 1989. 


\section{След едно обширно изложение по отношение на теософските сим-} волики и кратка стилистична характеристика на „Богомилски легенди“ М. Кремен засвидетелства и първите напрежения в отношенията между семейство Грозеви и Н. Райнов:

То [съзнанието ${ }^{7}$ на М. Кремен, б.м., Е. А.] узна само едно - че Николай Райнов наистина е даровит писател, но според Грозеви - неотрезвяващ Себелюбец и самомнителен Гений (БИА - НБКМ, ф. 651, а.е. 7, л. 3474).

През 1912 година те бяха вече пленници на Аноним. Вегетарианци и въздържатели дотогава, той ги научи да ядат месо и пият вино, мастика и абсент. Стоеше с часове у тях [...] Долу, на пода, стоеше до него недоизпита бутилка. [...] (БИА - НБКМ, ф. 651, а.е. 7, л. 3475).

Следва разказът на Иван Грозев:

С Николай Райнов се запознахме на теософските сказки, които ставаха на улица „6 септември“ 48. Първите ни впечатления бяха хубави. Смятахме го за рядък човек, за гений, което съдехме от „Богомилските легенди“. Представяше се за Посветен, който имал работа с Велики Учители. Донасяше свои рисунки, които представяха как изглеждал Боян Магьосникът, а и Ракоци - унгарският Велик Учител. Николай Райнов претендираше да е негов секретар [...].

И започнахме да го приемаме вкъщи [...]. Определихме една стая за заседанията на „Богомилското общество“, което ние образувахме и държахме в тайна. В него бяхме само пет души: Николай Райнов, Никола Трифонов, Борис Василев, Мица и аз. Софрони Ников странеше [...]. Хранеше се у нас често. Ние купувахме вермут на ден по кило. Купувахме и гроздова ракия. Той ни научи да пием - убеди ни, че не трябвало да се въздържаме. Понеже живеем между хора, на които трябва да въздействуваме, препоръчително било месояденето и пиенето. Той ни внушаваше, че имал „окултни способности“ $[. .$.$] .$

Той се мъкна у нас цели месеци - чак до 1913 година през време на войната. Кичеше се, че бил прероден Едгар По. Друг път - апостол Лука [...]. Въобще искаше да се изкара за голям маг [...]. След като го разбрахме, ние го изпъдихме, но той задигна купуваните с наши пари окултни книги на френски и немски. Райнов не знаеше немски, а писа, че превел „Заратустра“ от оригинала. Велико бе нашето търпение спрямо тоя човек! (НА - НБКМ, ф. 651, а.е. 7, л. 3496).

Оказва се, че между Иван Грозев и Николай Райнов темите, идеите, мотивите и образите често дори са общи. На пръв поглед всеки читател би възприел това като единомислие на творците, последователи на

7 На места в спомените, останали в архив, М. Кремен говори за себе си в трето лице, единствено число - това е предимно в случаите, когато разказва за младежката си влюбеност в съпругата на Грозев, Мария. 
теософията. На втори прочит обаче се откроява не някакво творческо взаимодействие ${ }^{8}$, а творческо изместване - представяне на механизми за себемитологизиране (от страна на Н. Райнов) за сметка на съзнателно засенчване на друг творец (по посока на Иван Грозев). Това разкрива специфичен процес на творческо подражание, а ако се съди по-строго, дори би се стигнало до идеята за заимствания и съперничество.

Би ли могъл някой да устои на тия съблазни, на пищното велелепие от мисли, дръзновения, поуки, спущани из устата на неизчерпаемия Рог на изобилието, без да се влюби в Чародея, нарекъл се Аноним?

И ето, че се намери устойчива жена, която е създадена за добро, ала не прави зло! Тя не глътна въдицата на българския Маг, не пи от сладката му отрова, а се помъчи да се отърве от него вежливо и деликатно (ЦДА, ф. 80 К, оп. 2 , а.е. 211 , л. 14$)$.

Така завършват спомените на М. Кремен за моментите на запознанство и близко общуване. Може би истинската причина за разрива на отношенията между двамата да е по-дълбока. Статията на Грозев по повод Райновия превод на „Тъй каза Заратустра“ свидетелства за отрицателното му отношение към преводаческите възможности на семинариста. Отпечатан през 1919 г., този превод на Ницше предизвиква естествените реакции на читателската публика в България 9 . Рецензията на Грозев е също част от този отзвук, който повдига въпроса за превеждането на Ницше. Грозевата статия разкрива и нещо много съществено от българския културен живот към 1919 г. - българският читател има изградени критерии, представи и разбирания за преводната философска книжнина.

Рецензията „Тъй рече Заратустра“. Ницше, неговите четци и преводачи“ (Грозев, 1919a, 1919b) е поместена в два поредни броя на в. „Напред“. Силният полемичен дух в нея се поддържа от богатата ерудиция на Грозев, който свободно и умело борави с немски, френски и руски, включва дори английски позовавания. Статията започва с теоретично изложение и философско тълкуване на основни постулати при Ницше - мотиви и образи, които по-нататък ще разкрие, че са несполучливо преведени, обяснени и изобщо разбрани от Николай Райнов.

8 Такъв е примерът с образа на Боян Мага, пресъздаден от Ст. Михайловски, К. Христов и Ив. Грозев и с контекстови и паратекстови връзки между тримата творци, което е свидетелство за тяхното творческо взаимодействие.

9 Тя е третият превод на книгата на Ницше в България. Първият е от 1905 г. на Дим. Дечев, а вторият - на М. Белчева, от 1915 г. 
„Тъй рече Заратустра“ е книга с мистичен лъх, написана с притчи и алегории в стила на свещените писания на Изтока и Запада [...] Да се преведе тая книга на български е цял подвиг, за който човекът трябва да е добре подготвен и да е пребродил всички стари и нови пътища на духовно търсене и постигане. И ние се надявахме, че тоя подвиг ще извърши г. Николай Райнов - човекът, който има претенцията да е избродил уж всички тези пътища, но - оставаме излъгани (Грозев, 1919а).

За Грозев в Райновия превод идеята на Ницше е „неверно предадена“, текстът е „неразбран“, „зле преведен“, има „неразбиране на оригиналния текст“. „Райнов се е повел по френския превод“, е констатацията на критика. Успоредно с Райновия текст, Грозев дава ясен, философски обоснован и верен превод на пасажите, като обяснява определени фразеологични изрази. Позовава се и на спецификата на мистичната литература и възкликва:

Тия тънкости г-жа Белчева може и да не ги знае, но г. Райнов? - Той, ученикът на окултизма и Теософията, - който е прочел Секретната Доктрина на Е. П. Блаватска, и който често цитира Бхагават-гита? (Грозев, 1919b).

Слаба, според критичния му прочит, се оказва и стилистиката на Райнов:

Изобщо, що се отнася до тоя превод, езикът на г. Райнова е изпълнен с какофония - усилена от многосложни и едносложни думи, както и от некрасиви звукосъчетания. [...] Цялата книга е изпълнена с такива скоропоговорки, в които не трябва да дириш смисъл (Грозев, 1919b).

Но не е достатъчно да бъде изобличен като слаб преводач. Това е само поводът, който събужда пристрастието на Грозев. Недостатъците в превода се съпътстват с такива и в творчеството - според Грозев Райнов заимства идеи и образи:

[...] Райнов притежава един голям талант - да си присвоява чуждото и сръчно да го приспособява; той неподражаемо подражава и ни дава един необикновен оригинален стил - пъстра пяна, черпена от всички морета на света... Така в предговора на неговите „Богомилски легенди“ (виж 1 изд. - б.а., И. Гр.) ние намираме цели изрази, заети дума по дума, от Балмонта (Грозев, 1919b) [подч. мое, Е. А.].

От характеристика на преводаческото и художественото творчество Грозев преминава към изобличение на авторовото поведение у своя довчерашен приятел: 
По-важни са обаче мистификациите на г. Райнова, с които той иска да изпъкне пред тълпата зяпачи като някакъв маг и да придаде по-голяма тайнственост на това, що пише, както и да се облече сам в легенда (Грозев, 1919b) [подч. мое, Е. А.].

„Отговорът“ на Райнов не закъснява и е във връзка с издадената през 1922 г. антология „Млада България“ под редакцията и с предговор от Иван Радославов (Радославов, 1922). В нея са представени и Николай Райнов, и Иван Грозев. По-напред в съдържанието е Грозев, той е непосредствено след „класиците“ на символизма Теодор Траянов, Трифон Кунев, Людмил Стоянов, Николай Лилиев, Емануил Попдимитров и Димчо Дебелянов. Грозев е представен с 15 творби, а Райнов - с 3.

По „целната и художествена индивидуалност“ поне на едната третинка от представените в сборника може да се спори [...] между тях има две-три имена, които не са имена на поети... Има неколцина, които се още лутат - и чийто творчески път не е съвсем ясен дори за оногова, който ги знае наизуст. Па има и някои, които се повтарят или повтарят другите [...] Накъсо казано - [...] редом с хубавите и благовонни цветя има и много буренак, и много троскот, и много магарешки бодил дори... (Н. Райнов, 1922, с. 4).

Разсъжденията на Райнов се базират изцяло на краткия увод от Радославов, в който той очертава принципите на подбор. Привидно критическите пасажи се отнасят до Радославовия избор, но на втори план се разчитат като адресирани до творците, заели по-предно и по-представително място от Райнов в антологията, и трето, но не последно място, посланията са отправени и специално към Ив. Грозев. Всяко отрицателно заключение на обидения творец започва или завършва с Грозев.

Целните и определени художествени индивидуалности начеват, както е явно по сборника, от Т. Траянов и Л. Стоянов, за да свършат с Ив. Грозева и К. Тодорова (Н. Райнов, 1922, с. 4) [подч. мое, Е. А.].

Райновите критики се отнасят и към „средствата на една нова естетика“ - естетиката на символизма. Според Радославовия предговор символизмът се основава на изключването на „всякакъв изкуствен патос, всяка реторика, всяка доказана логика, всяка яснота на образа“. Райнов отговаря:

[...] Но пък има ли нещо по-ясно от образите на Хр. Ясенов, Д. Дебелянов, К. Тодорова, Ив. Грозева - особено на последните двама? Яснота може да има и у най-плоските поети, мъгливост може да има и най-големите творци [...] (Н. Райнов, 1922, с. 4). 
Така Райнов опровергава не само Радославов като критик, не само групата „Хиперион“ като модерни творци, но засяга твърде отчетливо и мистично-символистичната образност на Грозевото творчество. Като поставя проблема за символизма и присъствието му в антологията „Млада България“, Райнов смята, че представата за „български символизъм“ е съчинена.

Като средство в изкуството - симболът е път, по който се обогатява и вдълбочава вторично творческият синтез, сиреч - за четеца (когато е дума за поезия) става да добие по непосредствен начин всички дадени, които му обуславят едно съпреживяване с поета, добил от него градивото; той вниква в дълбочините, що му сочи магът на словото, за да опознае накрай, че те са дълбочини и на неговата собствена душа, - лично да преживее трагедията на твореца, да се самообогати, да постигне себе си (Н. Райнов, 1922, с. 4).

Забелязва се сходна пунктуалност между Грозевия и Райновия текст - те използват едни и същи образи, за да опишат творческия процес. Той е „път“, който подлежи на „извървяване“ от неопитния „четец“, воден от посветения „поет“, респ. „преводач“. Творецът пък е „маг на словото“, който вниква в „дълбочини“, за да „постигне себе си“.

Според Райнов не е добър и подборът на автори и творби в антологията „Млада България“. Тук отношението към Грозев е снизходително - посочен е като първи, преди Траянов, творец, обаче критикът преднамерено се позовава на недотам сполучливите му ранни творби (поезия и драматургия). В тези критически фрагменти се налага съпоставката между двамата творци. Ако Грозев е по-пунктуален и конкретен, то Райнов сякаш се плъзга по повърхността на конфликта. Той премълчава, но в неговото премълчаване се съдържа цялостното отрицание на Грозев като творец. Факт е, че на въпроса: „Кого смятате в българската литература за ярък представител на мистицизма?“, зададен от Ж. Нурижан, Грозев отговаря: „Някога написах възторжен отзив за Николай Райнов при появата на неговите „Богомилски легенди“ през 1912 г., но останах силно разочарован отпосле“ (Нурижан, 1940, с. 44) ${ }^{10}$.

Тази твърде пристрастна и комплицирана история не би звучала достоверно, ако не бяха свидетелствата за поведението на Н. Райнов и от

${ }^{10}$ Спомените на М. Кремен за Райнов са още по-осъдителни, когато минава на анализа на текста, посветен на П. К. Яворов във „Вечното в нашата литература“ (Н. Райнов, 1941). 
други творци - Ив. Радославов, Ст. Атанасов. Ето какво споделя последният в свои спомени:

Николай Райнов влезе в обществото неочаквано, като метеор. Всички се възхищаваха от неговите разкази на древна България, всички търсеха неговата дружба и познанство. Отначало той беше много скромен, въздържан, любезен, внимателен, мълчалив; но с течение на времето той полека-лека отблъсна и разочарова всички свои почитатели и поклонници, изгуби всички свои добродетели (НА на БАН, сб. ХІ, оп. 1, а.е. 47, л. 2).

Обаче с течение на времето суетата победи скромността и нашият приятел започна да става по-чувствителен към хвалбите (НА на БАН, сб. ХІ, оп. 1, а.е. 47 , л. 2 ).

И така, нашият скромен Н. Райнов полека-лека стана така суетен и чувствителен към своето високо положение, че почна да гледа на всички с едно едва уловимо презрение, като че ли на всички гледаше от висотата на Хималаите (НА на БАН, сб. XI, оп. 1, а.е. 47 , л. 7.).

В този „хор“ на критическо отношение към литературната продукция и към естетиката на символизма, прокламирани от „Хиперион“, се включва и Ст. Младенов - по повод на антологията „Млада България“ (1922 г.). Вероятно и Ст. Младенов не би написал своята статия в „Листопад“ (Младенов, 1924), ако преди това не беше факт статията на Грозев. Всъщност „Декаденти и семковщина“ е заглавие на критически материал и на Ст. Младенов, и на Н. Райнов. Първа излиза тази на Ст. Младенов, а в следващ брой, като по-късна реплика, е отзивът на Н. Райнов. Докато статията на Ст. Младенов е изпълнена с искрена позиция - несъгласие, възмущение, протест, дори на места ярост, то статията на Н. Райнов е повече поза, която държи да утвърди опита си за диспут с по-ранната своя статия във в. „Слово“ (написана също по повод на „Млада България“). И докато критическото перо на Ст. Младенов предизвиква интеpec, то Райнов сякаш изразява само някакво смътно намерение от типа „И аз това исках да кажа...“. Райнов не умее да води литературна полемика, Грозев е много по-силен от него в това. В материала на Н. Райнов има и едно малко, но важно пояснение - „Статията съдържа мислите, които професорът бе изложил миналата година в своята сказка, държана в София и повторена отсетне в Пловдив“ (Н. Райнов, 1925a, с. 30). Следователно полемиките около „Млада България“, задругата „Хиперион“ и прокламирания символизъм са били обект на дискусия дълго време в публичното пространство. 
Така гласовете „за“ сектантството на теософията в редиците на изкуството се умножават. И докато за редактора на „Златорог“ е логично да охранява границите на своето списание, за рано напусналия „Хиперион“ Н. Райнов е обяснимо да се разправя със съперника си и в мистицизма, и в живота, и в изкуството, то за Й. Бадев на пръв поглед такава полемика не звучи толкова убедително ${ }^{11}$.

Статията „Походът срещу „Хиперион“ отразява позицията на Грозев спрямо нападките срещу списанието. Тя е пряка реакция по повод Йордан-Бадевата „Програма и изпълнение“, публикувана във в. „Слово“. Че статията на Й. Бадев е само част от мотивите, се разбира от „посвещението“ на статията - „На един от многото“. В уводната ѝ част поетът препотвърждава умението си да разбира „неща неуловими“, което се предполага не толкова от служебен пост („не стига само това да си професор в университет (дори и по литература), или по литература учител“ (Грозев, 1923, с. 366), а от уменията да „дешифрира“ закодираните символи или, казано на Грозевия език, чрез творческия процес на проживелииа да достигне до прозрение, а самото творчество се превръща в откровение. Също ясно е определена ролята на критика -

Оня, който претендира да бъде критик, трябва да има - освен чувствителна душа на поет - и един широк поглед, за да може да се откъсне от своите предвзети мнения и да бъде истински тълкувател на едно художествено творение, като проникне в неговата същина, измери глъбините му и даде вярна преценка (Бадев, 1923а, с. 4).

11 Към годините на тази полемика, 1923-1925, Й. Бадев, Л. Стоянов и Ив. Грозев са масони. Ем. Попдимитров е приет едва през 1933 г., а Н. Райнов - още по-късно, едва през 1940 г. От друга страна, Ив. Грозев и Н. Райнов са теософи, но техните отношения са се влошили още след 1912 г. Отношението между Й. Бадев и Ив. Грозев пък може да се обясни именно през и чрез принадлежността им към тайните общества. Й. Бадев членува в ложа „Светлина“. Приет е през 1921 г. и е един от участниците в Международния масонски конгрес в Париж (Недев, 2009, с. 475). Иван Грозев става член на ложа „Зора“ през 1918 г. (Недев, 2009, с. 4). Н. Райнов е приет в ложа „Зора“ едва през 1940 г. - в самия край на легалното българско масонство от първата половина на XX век (Богданов, 1994, с. 126). Ложите „Зора“ и „Светлина“ се създават на 20 ноември 1917 г., когато първосъздадената ложа „Заря“ се раздвоява на две и се образува Великата Ложа на България (Андонова, 2011, с. 74). Още В. Георгиев (Георгиев, 1986), а по-късно и Ив. Богданов (Богданов, 1994) обръщат внимание на факта, че част от масоните в България от първата половина на ХХ век поддържат представата за симбиоза между мистицизъм и масонство, докато друга част от тях не приемат това. Повече по този въпрос вж. Азманова-Рударска, 2018. 
В тази полемика „хиперионецът“ защитава литературните позиции на задругата, но и различните естетически вплитания, включително и най-вече мистицизма. С присъщата си патетичност Грозев призовава: „Не засягайте мистицизма, господа!“. След емоционалната възхвала на силата на мистицизма критикът го поставя в основата на творчеството - „Изкуството по същина е мистицизъм“.

В своя „отговор“ Й. Бадев го обвинява в неумение да различава въображение от опит и удобно подминава един от най-убедителните примери от страна на Грозев за изясняване на същностите - Грозев се позовава на авторитети от световната литература като Гьоте и Стриндберг. Бадев удобно пропуска втория, като анализира мистицизма само на първия. Грозев в ясен текст, макар и поставен в скоби, заявява своята принадлежност към теософията и това се оказва препъникамъкът:

[...] В наши дни един Стриндберг, който пише „Адвент“ и „Към Дамаск“, е също тъй мистик и - нещо повече - член на Теософското общество (какъвто съм и аз - а не сектант адвентист, г. Бадев!) (Грозев, 1923, с. 368).

Докато Грозев разбира мистицизма надвремево и надпространствено и всеки мистицизъм е сроден помежду си, а теософията е част от глобалното му разбиране за мистицизма, то за Бадев мистицизъм и теософия са различни неща, още повече през различно време и за различни епохи. Спорьт между Бадев и Грозев не може да има решение. Бадев се опитва да продължи тази полемика и отговаря на Грозев отново в „Слово“, този път в статията „Поезия и сектантство“ (Бадев, 1923b). Тази разгорещена дискусия продължава и след статията на Грозев - тогава се включват и Ив. Радославов, М. Бенароя, Вл. Василев и др.

Двамата теософи, бивши приятели, превърнали се в литературни противници, биват различно оценени и от литературната критика по отношение на тяхното противоборство - кой от двамата е „повече мистик”, кой е по-добър творец. Оценката идва само десетина години след разразилата се полемика, и то от критик, който в същото време е и масон - Цветан Минков $^{12}$. В изследването си върху история на драмата учителят по

12 Цветан Николов Минков (1891-1967) е български писател, литературен историк и критик, учител, фолклорист, масон. Завършва славянска филология в СУ „Св. Климент Охридски“ през 1914 г. Учител в Лом, Бургас, София, Ихтиман. Редактор на библиотеките „Литературни разбори“ и „Родна книга“ (1929-1939). Член на СБП. Сътрудничи на редица издания в периода между двете световни войни. Автор 
литература поставя творбата на Н. Райнов „Имало едно време“ в раздела „Историческа драма“ и го определя като „автор на много исторически сказания, често в бедна фабула и статично-декоративен стил“ (Минков, 1936, с. 110). Макар да забелязва, че драмата е „облъхната от мистицизъм и философски елемент“ (Минков, 1936, с. 110), Минков не я приема за сполучлива и изтъква редица проблеми в нея - „драмата е книжна“, „преломът у Владимир не е изяснен“, „лицата не са очертани като герои на действие, а символически“, „Езикът е статичен, разточен, неподчинен на драматически цели“ (Минков, 1936, с. 111). По отношение на Б. Дановски, чиито творби критикът също поставя в групата на „Историческа драма“, с одобрение отбелязва, че „разкрива мистериите на душата, отхвърля привидната реалност“, „копнежът по загадъчното движи волята“, „драмата му е синтетична“ (Минков, 1936, с. 112). Симпатиите на Минков преминават в оценка, която, интересното е, че зависи от степента на мистичност - „Така той доразвива неоромантиката на Стоянова, доближава се до мистиката на Грозев и Караджов“, като подчертава „дълбоката идейност на драматическите му видения (1924). Националното у него се претворява в космополитно“ (Минков, 1936, с. 112). Заключението обаче по отношение на Н. Райнов е твърде бегло, като не изтъква достижения, а само разкрива влиянията на западноевропейската литература: Драмата напомня „Дон Карлос“ от Шилер със своя идеалистически патос и вяра в човека. Раутенделайн от потъналата камбана на Хауптман е внушила на автора образа на Светла, демоничното е внесено под влияние на Луцифер на Байроновия „Каин“ (Минков, 1936, с. 112).

Тези два примера - оценките на драматургичните творби на Райнов и на Дановски - разкриват задълбоченото познаване на мистичното и неговата сюжетопораждаща основа. Те са и показателни за отношението към Райновото творчество - критиката все пак отрежда превес на Грозев за сметка на Райнов в изобразяване на мистичното в българската литература.

С това не приключват отношенията между Н. Райнов и Ив. Грозев. Те се усложняват все повече след 1944 г. Интригата се заплита с факта, че след 1944 година са оставени без последствия и Грозевото, и Райновото участие

на 12 исторически романа и множество по-малки очерци и разкази. Съставител на учебни помагала по литература, учебници, христоматии и читанки (Цанев, 1977, c. 379). Член на ложа „Зора“ към Великата ложа на България преди 1932 г. 
в мистични и теософски организации. Според 3. Андонова и двамата са били привикани за обяснения след 1944 година в отделите на МВР (Архив МВР, Лит. дело VI Л, 719, т. I, ч. I; цит. по: Андонова, 2011, с. 124).

В ЦДА се съхраняват сведения и обяснения по въпросите за масонството и теософията, събирани от страна на сектор „Партийна информация“ при ЦК на БРП (к). Сред тях се пазят списьците с членовете на над 9 ложи с общ обем 65 листа, изготвени на 10 февруари 1949 г. Според документите на ложа „Зора“, където фигурира под № 22, Иван Грозев е „член на ложата от 1918 г., писател - теософ“ (ЦДА, ф. 401Б, оп. 1, a.e. 16). В „Списька на управителните тела (сановници) на ложа „Зора“ за 1918 г. Ив. Грозев е избран за Втори надзирател, почетен майстор на ложата е П. Мидилиев, Първи надзирател е Д. Спространов, блюстител е Ал. Теодоров-Балан.

Към този архив се причислява и списъкът с членове на масонски ложи в София и провинцията (б.д.) (ЦДА, ф. 401Б, оп. 1, а.е. 17), предназначен за новата власт. Четат се имената на 465 души, повечето - известни личности. Иван Грозев е под № 79, като е подчертан с черна писалка (мастилена). Така са обозначени имената и на Цв. Минков, К. Петканов. Срещу тях е отбелязано, че Цв. Минков е „чл. РПк“ („член Работническа партия, комунисти“), а К. Петканов е от „Звено“ (ЦДА, ф. 401Б, оп. 1, а.е. 15, л. 13, л. 15). Странен е фактът, че в този дълъг списък на приети и членували през различно време хора, живи към настоящия момент или покойници, липсва името на Н. Райнов.

Сред сведенията обаче, давани пред новата власт след 1944 г., се откриват писмените изложения на проф. Благой Мавров (ЦДА, ф. 401Б, оп. 1, а.е. 25), София Мангърова (ЦДА, ф. 401Б, оп. 1, а.е. 26) и „писателя Николай Райнов“ (ЦДА, ф. 401Б, оп. 1, а.е. 29).

В доклада на Благой Мавров ${ }^{13}$, професор към Българската музикална академия, „секретар на първична партийна организация и преподавател във военната академия по френски език“, четем:

Основател на смесеното масонство аз считам Софрони Ников и Ив. Грозев. Инициативата за неговото основаване не произлиза от Великата ложа на Бълга-

13 Благой Мавров (1897-1967) завършва филология и музикално образование в Италия, а в София - Рисувалното училище и Софийския университет, френска филология (1926). През 1950 г. става професор в Българската държавна консерватория. Преводач, автор на българо-италиански и българо-френски речници. През 1967 г. е награден с орден „Червено знаме на труда“ (ЦДА, ф. 1976К, оп. 1, а.е. 10). 
рия. Аз считам, че инициативата произлиза от ръководството на Английската либерална църква, със седалище Лондон, на която са свещеници Ив. Грозев и Софрони Ников. И двамата бяха реакционери и след споровете ни с тях аз, проф. Ник. Райнов и много други по-прогресивни деятели напуснахме масонските ложи (ЦДА, ф. 401Б, оп. 1, а.е. 25).

След текста с думите на проф. Мавров стои напечатано на пишеща машина „Бележка на „П. И.“"

Благой Мавров е може би единствения от видните масони, станали в последствие членове на нашата партия, който съвършено искрено е отбелязал в своята автобиография (дадена на партията), че в миналото е бил масон (ЦДА, ф. 401Б, оп. 1, a.e. 25).

София Мангърова също разказва интересно и увлекателно, но тя не придава идеологическа окраска на думите си.

Много полярен обаче е Н. Райнов. Ето части от изложението му:

Аз членувах в масонската ложа „Парсифал“ през 1931, 1932 и 1933 година. Напуснах след като влязох в конфликт с водача на смесеното масонство Коста Стефанов - богат човек, директор на фирмата „Братя Баджови“. Същият бе Велик майстор. Велик секретар бе Андре Тюрьо, представител на фирмата „Мерцедес“ и други чужди фирми (ЦДА, ф. 401Б, оп. 1, а.е. 29, л. 1-3).

И в сведенията на Мавров, и в тези на Райнов прозира новата атеистична идеология. Мавров споменава Ив. Грозев над 7 пъти, а у Райнов - поне 3 пъти. И двамата подчертават не само водещата роля на Грозев, но и разкриват лична обида. В новосъздалата се политическата обстановка звучат като обвинители. По това време Н. Райнов става председател на Съюза на художниците по същия начин, по който се сменя управата на Съюза на българските писатели - с особената намеса на Партията и с репресивните методи на новата власт.

Като съпоставка с поведението на Райнов е референцията на Иван Грозев пред Народния съд. На 21 март 1945 г. той е призован в качеството си на свидетел за подсъдимия Асен Ив. Боев. Ето какво съобщава Грозев:

Познавам Асен Боев. Срещал съм се с него 2 или 3 пъти. За неговата литературна дейност нищо не зная. Книгите му не съм чел. Той ми е направил впечатление на широко любознателен човек, на културен човек (ЦДА, ф. 1449, оп. 1, а.е. 157 , л. 242 ).

14 П.И. - „Партийна информация“, отдел който се е занимавал със събиране на сведения. 
Толкова. Без изтъкване или самоизтъкване, без желание за властване над ситуацията. Грозев е премерен, балансиран, добронамерен, неосъдителен.

Така новата власт след 1944 г., с промените в социален план, успява да направи нещо много повече - да отнеме идентификацията на българина, усещането му за принадлежност към по-голяма общност, събрана от идеи и цели. Нещо, което Иван Грозев никога не губи. Винаги съхранява принадлежността си към най-големия род - човешкия. Космополит в своите религиозно-философски и езотерично-мистични разбирания, той си остава българин в произведенията си.

Статията на Г. Димитров „Масонските ложи са национална опасност“ (Димитров, 1946) затваря дискурса на масонството в полето на идеологическата изолация. Така се стига до доклад, изготвен около 1948 г. от сектор „Партийна информация“ при ЦК на БРП (к) за масонските ложи в България, където масонството е заклеймено и отречено (ЦДА, ф. 401Б, оп. 1, а.е. 30).

Приключва се „по надлежния ред“ и с Теософското общество в България. С фирмено дело № 616 е прекратена дейността на едно спряло да функционира още през 1940 г. общество. Мотивите: всички членове са починали! Годината е 1954 година - все още са живи Грозев, К. Сагаев и др. Следователно някой се е погрижил тези хора да не бъдат дори разпитвани. И в този смисъл - запазени. Отношението към Грозев обаче е показателно и за нещо друго - за „засищане“ на жадната за реваншизъм нова система.

Познанството между двамата мистици, водещи в естетическите експликации на езотеричното в българската литература от първата половина на XX век, е продължително, колебливо, спорно, полемично, граничещо на места със скандала. Техните контакти са основани на многоизмерни и противоречиви прояви на приятелство, литературни полемики, синхронност на религиозно-мистичните идеи, личностни противопоставяния. Фундаментални за тяхното разминаване се оказват три допирни точки: красива жена, споделената опитност в мистичните учения и критичното им отношение към творчеството на другия. Това предопределя както стремежа им към оразличаване и отдалечаване един от друг до 1944 г., така и противоположните им пътища във времето на налагане на комунистическия атеизъм в България след 09 септември 1944 г. По един болезнен начин онзи творец, който е тръгнал от ортодоксалното християнство, завършва с безверие, разрушавайки всички мостове с мистичното. И другият, който започва своето търсене в света на религиозното през протестантската книжнина, никога не се отказва от мистичното и отстоява своите възгледи дори във 
време на безверие. Без да бъдат определящи като модел, нито достатъчни за по-мащабни обобщения, тези две страни на светоглед изразяват двамата творци по един оригинален начин. Каноничното и неканоничното се срещат не за да се сблъскат, а за да отбележат присъствие в специфичния свят на религиозно-мистичната българска литература.

Представените фактологични, публицистични и споменни материали очертават не само напрегнатостта в отношенията им, но и творческата инвенция на двамата - докато у Райнов се наблюдава апокалиптично-разрушаващата образност, то у Грозев преобладават патетично-възторженото издигане на духовното. Извънлитературната полемика белязва живота им, творческите им търсения и експликации. Дори и в най-близките до християнската доктрина творби Райнов остава бунтар. Дори и в най-мистичните си видения Грозев запазва своята въздържаност и приземеност. Нещо повече, емблематичните сборници на Райнов „Богомилски легенди“, „Видения из Древна България“ и „Книга за царете“ носят усещането за преминаване на границите, където образите на светци и еретици са избрани неслучайно - те показват нарушението на канона и в най-съвършения от тях. Обратно, в драмите на Грозев (особено в „Златната чаш““, „Йов“ и „Съдний ден“) присъстват образи, които подлежат на преобразяване и извисяване, на духовна трансформация и дори мистична инкарнация. Макар и двамата да интерпретират сходни теми (богомилството, теософията, мистицизма) и дори мотиви (Боян Магьосника, фолклорни и антични сюжети), творческите им механизми и подходи спрямо религиозно-мистичната проблематика, като претворяване (Грозев) или снаждане (Райнов), превръщат Грозев в неканоничен кандидат за Нобелова награда (Азманова-Рударска, 2018, с. 184), а Райнов - в класик с отменен, забранен юбилей (С. Райнов, 1978, с. 134).

\section{БИБЛИОГРАФИЯ}

Азманова-Рударска, Е. (2018). Иван Грозев в българската литература: Социални, политически, исторически и религиозно-мистични контексти, полемики и диалози. Рива. Андонова, 3. (2011). Масонство и масони в България. УИ „Св. Климент Охридски“. Бадев, Й. (1923a, June 25). Програма и изпълнение. Слово.

Бадев, Й. (1923b, October 22). Поезия и сектантство. Слово.

Богданов, И. (1994). Синовете на вдовицата: Масонство и масони. УИ „Св. Климент Охридски“. 
Бънян, Д. (1866). Пътешественикът от този свят до онзи или Християновото пътешествие от градът Погибелово до Небеснийт град: Казано в подобие на съновидение om Иоанна Бъняна (А. Лонг, Trans.). В книгопечатницата на А. Минасияна.

Георгиев, В. (1986). Масонството в България: Проникване, организация, развитие и роля до средата на тридесетте години на ХХ век. Наука и изкуство.

Георгиева, Ц. (2008). Unio mystica и българският символизбм. За буквите - о писменехь. Головински, Е. (Еd.). (1999). Българска енциклопедия „A- Я“. Труд.

Грозев, И. (1919a, September 1). Тъй рече Заратустра: Ницше, неговите четци и преводачи. Напред, 1919(65), 1.

Грозев, И. (1919b, September 2). Тъй рече Заратустра: Ницше, неговите четци и преводачи (Втора част). Напред, 1919(66), 1.

Грозев, И. (1923). Походът срещу „Хиперион”. Хиперион, 1923(6-7), 366-369.

Джевиецка, Е. (2010). Инверсията като негация: Образът на Юда в романа на Николай Райнов Между пустинята и живота. Научни трудове - Пловдивски университет „Паисий Хилендарски“: Филология, 48(1), 148-158.

Джевиецка, Е. (2017). Българската реформация? За хибридизацията на идеите в процеса на модернизацията на културата. Slavia Meridionalis, 17. https://oi.org/10.11649/sm.1370

Димитров, Г. (1946, July 22). Масонските ложи са национална опасност. Работническо дело, 1946(20).

Димитрова, Н. (2008). Дебати около българския гностицизъм - ХХ век. Фабер.

Добринов, В. (Ed.). (1922). Жътва: Литературно-художествен сборник. Слънце.

Илчев, И., \& Митев, П. (2003). Докосвания до Америка (ХІХ - началото на ХХ век). Фондация Хемимонт.

Куличев, Х. (2008). Заслугите на протестантите за българския народ. УИ „Св. Климент Охридски“.

Минков, Ц. (1936). Българската драма: Начало, развитие, представители. Факел.

Младенов, С. (1924). Декаденти и семковщина. Листопад, 1924(9-10), 225-253.

Недев, Н. (2009). Българското масонство (1807-2007). Хермес.

Нурижан, Ж. (1940). Стожери на българската литература: В два тома (Vol. 2). Доверие.

Памуков, С. (1989). Поглед към неизвестното: Писма, стихотворения, изповеди. Представени от С. Памуков (А. Свиленов, Еd.). Хр. Г. Данов.

Пилева, М. (2018). Бунт, надежда, изкупление. (Англоезичните преводи от българския ХІХ век). Кралица Маб.

Радославов, И. (Ed.). (1922). Млада България: Антология на съвременната българска поезия 1905-1922. Хиперион.

Райнов, Н. (1922, June 12). Литературна седмица: „Млада България“. Слово, 1922(49), 2.

Райнов, Н. (1925а). Декаденти и семковщина. Листопад, 1925(1), 30-32.

Райнов, Н. (1925b). Днес и утре: Мистика и безверие; Блян ли е сврбхчовекът; Копнежът на народите. Акация.

Райнов, Н. (1941). Вечното в нашата литература: Български класици. Свободни беседи, книжка 1-9: Vol. 7. Пейо Яворов, Теодор Траянов. Ст. Атанасов.

Райнов, Н. (2003). Между пустинята и живота. Захари Стоянов. 
Райнов, С. (1978). Николай Райнов. In Рачо Стоянов, Николай Райнов, Стоян Загорчинов, Константин Константинов в спомените на съвременнииите си. Български писател.

Цанев, Г. (Ed.). (1977). Речник на българската литература: В три тома (Vol. 2). Издателство на БАН, Институт по литература.

Цанев, Г. (Ed.). (1982). Речник на българската литература: В три тома (Vol. 3). Издателство на БАН, Институт по литература.

Стойчева, С. (1991). Между пустинята и живота - роман на българския модернизбм. Литературна история, 1991(19), 26-38.

Стойчева, С. (2007, June 6-12). Окултният символизъм на Николай Райнов. Литературен вестник, 17(22), 4.

Сугарев, Е. (2007). Николай Райнов - боготърсачът богобореи. Карина - Мариана Тодорова.

Сугарев, Е., Димитрова, Е., \& Атанасова, Ц. (Eds.). (2009). Критическото наследство на българския модернизбм (Vol. 3). Боян Пенев.

Трендафилов, В. (1991). Явлението Николай Райнов. Литературна мисъл, 35(8), 31-93.

Шват-Гълъбова, Г. (2010). Haeresis bulgarica в българското културно съзнание на ХІХ u XX век (В. Деянова \& Г. Коминек, Trans.). УИ „Св. Климент Охридски“.

\section{BIBLIOGRAPHY}

\section{(TRANSLITERATION)}

Andonova, Z. (2011). Masonstvo i masoni v Bŭlgariia. UI “Sv. Kliment Okhridski”.

Azmanova-Rudarska, E. (2018). Ivan Grozev v bŭlgarskata literatura: Sotsialni, politicheski, istoricheski i religiozno-mistichni konteksti, polemiki i dialozi. Riva.

Badev, Ĭ. (1923a, June 25). Programma i izpŭlnenie. Slovo.

Badev, Ĭ. (1923b, October 22). Poeziia i sektantstvo. Slovo.

Bogdanov, I. (1994). Sinovete na vdovitsata: Masonstvo i masoni. UI “Sv. Kliment Okhridski”.

Bŭnian, D. (1866). Pŭteshestvenikŭt ot tozi sviat do onzi ili Khristiianovoto pŭteshestvie ot gradŭt Pogibelovo do Nebesniüt grad: Kazano v podobie na sŭnovidenie ot Ioanna Bŭniana (A. Long, Trans.). V knigopechatnitsata na A. Minasiiana.

Dimitrov, G. (1946, July 22). Masonskite lozhi sa natsionalna opasnost. Rabotnichesko delo, 1946(20).

Dimitrova, N. (2008). Debati okolo bŭlgarskiia gnostitsizŭm - XX vek. Faber.

Dobrinov, V. (Ed.). (1922). Zhŭtva: Literaturno-khudozhestven sbornik. Slŭntse.

Dzhevietska, E. (2010). Inversiiata kato negatsiia: Obrazŭt na IUda v romana na Nikolaŭ Raŭnov Mezhdu pustiniata i zhivota. Nauchni trudove - Plovdivski universitet "Paisiŭ Khilendarski": Filologiia, 48(1), 148-158.

Dzhevietska, E. (2017). Bŭlgarskata reformatsiia? Za khibridizatsiiata na ideite v protsesa na modernizatsiiata na kulturata. Slavia Meridionalis, 17. https://doi.org/10.11649/sm.1370 
Georgiev, V. (1986). Masonstvoto v Bŭlgariia: Pronikvane, organizatsiia, razvitie i rolia do sredata na tridesette godini na XX vek. Nauka i izkustvo.

Georgieva, T. (2008). Unio mystica i bŭlgarskiat simvolizŭm. Za bukvite - o pismenekh.

Golovinski, E. (Ed.). (1999). Bŭlgarska entsiklopediia “A - IA”. Trud.

Grozev, I. (1919a, September 1). Tŭĭ reche Zaratustra: Nitsshe, negovite chettsi i prevodachi. Napred, 1919(65), 1.

Grozev, I. (1919b, September 2). Tŭŭ reche Zaratustra: Nitsshe, negovite chettsi i prevodachi (Vtora chast). Napred, 1919(66), 1.

Grozev, I. (1923). Pokhodŭt sreshtu "Khiperion”. Khiperion, 1923(6-7), 366-369.

Ilchev, I., \& Mitev, P. (2003). Dokosvaniia do Amerika (XIX - nachaloto na XX vek). Fondatsiia Khemimont.

Kulichev, K. (2008). Zaslugite na protestantite za bŭlgarskiia narod. UI “Sv. Kliment Okhridski”. Minkov, T. (1936). Bŭlgarskata drama: Nachalo, razvitie, predstaviteli. Fakel.

Mladenov, S. (1924). Dekadenti i semkovshtina. Listopad, 1924(9-10), 225-253.

Nedev, N. (2009). Bŭlgarskoto masonstvo (1807-2007). Khermes.

Nurizhan, Z. (1940). Stozheri na bŭlgarskata literatura: V dva toma (Vol. 2). Doverie.

Pamukov, S. (1989). Pogled kŭm neizvestnoto: Pisma, stikhotvoreniia, izpovedi: Predstaveni ot S. Pamukov (A. Svilenov, Ed.). Khr. G. Danov.

Pileva, M. (2018). Bunt, nadezhda, izkuplenie. (Angloezichnite prevodi ot bŭlgarskiia XIX vek). Kralitsa Mab.

Radoslavov, I. (Ed.). (1922). Mlada Bŭlgariia: Antologiia na sŭvremennata bŭlgarska poeziia 1905-1922. Khiperion.

Raĭnov, N. (1922, June 12). Literaturna sedmitsa: "Mlada Bŭlgariia”. Slovo, 1922(49), 2.

Raĭnov, N. (1925a). Dekadenti i semkovshtina. Listopad, 1925(1), 30-32.

Raĭnov, N. (1925b). Dnes i utre: Mistika i bezverie; Blian li e svrŭkhchovekŭt; Kopnezhŭt na narodite. Akatsiia.

Raĭnov, N. (1941). Vechnoto v nashata literatura: Bŭlgarski klasitsi. Svobodni besedi, knizhka 1-9: Vol. 7. Peйo IAvorov, Teodor Traianov. St. Atanasov.

Raĭnov, N. (2003). Mezhdu pustiniata i zhivota. Zakhari Stoianov.

Raĭnov, S. (1978). Nikolaĭ Raĭnov. In Racho Stoianov, Nikolă Raĭnov, Stoian Zagorchinov, Konstantin Konstantinov v spomenite na sŭvremennitsite si. Bŭlgarski pisatel.

Shvat-Gŭlŭbova, G. (2010). Haeresis bulgarica v bŭlgarskoto kulturno sŭznanie na XIX i XX vek (V. Deianova \& G. Kominek, Trans.). UI "Sv. Kliment Okhridski”.

Stoŭcheva, S. (1991). Mezhdu pustiniata i zhivota - roman na bŭlgarskiia modernizŭm. Literaturna istoriia, 1991(19), 26-38.

Stoĭcheva, S. (2007, June 6-12). Okultniiat simvolizŭm na Nikolaŭ Raŭnov. Literaturen vestnik, 17(22), 4. Sugarev, E. (2007). Nikolaĭ Ră̌nov - bogotŭrsachŭt bogoborets. Karina - Mariana Todorova.

Sugarev, E., Dimitrova, E., \& Atanasova, T. (Eds.). (2009). Kriticheskoto nasledstvo na bŭlgarskiia modernizŭm (Vol. 3). Boian Penev.

Trendafilov, V. (1991). IAvlenieto Nikolaŭ Raĭnov. Literaturna misŭl, 35(8), 31-93.

TSanev, G. (Ed.). (1977). Rechnik na bŭlgarskata literatura: V tri toma (Vol. 2). Izdatelstvo na BAN, Institut po literatura. 
TSanev, G. (Ed.). (1982). Rechnik na bŭlgarskata literatura: V tri toma (Vol. 3). Izdatelstvo na BAN, Institut po literatura.

\section{Chrześcijaństwo, mistycyzm, niewiara. Iwan Grozew i Nikołaj Rajnow}

Artykuł jest poświęcony osobistym i artystycznym relacjom między dwoma słynnymi bułgarskimi poetami i mistykami, Iwanem Grozewem i Nikołajem Rajnowem. Przed rokiem 1944 życie obu upływa pod wspólnym znakiem kolejno ortodoksyjnego chrześcijaństwa, spirytyzmu, teozofii i wolnomularstwa. Do rozdziału dochodzi po 1944 roku, kiedy Rajnow odrzuca wszelkie formy religijności. Na początku ich wzajemny stosunek jest pozytywny, ale z czasem dochodzi do ostrych sporów. Pierwsze słowa krytyki wypowiada Grozew. Sprawa dotyczy przekładu Rajnowa Tako rzecze Zaratustra Friedricha Nietzschego. Dalsza polemika z jednej strony ma istotny wpływ na część elit intelektualnych w Bułgarii, z drugiej - ilustruje zmieniający się stosunek obu pisarzy do religijności. Materiał źródłowy stanowią archiwa, wspomnienia i autobiografie. Odsłaniają one dialogiczność w bułgarskiej literaturze w pierwszej połowie XX wieku.

Słowa kluczowe: Iwan Grozew, Nikołaj Rajnow, chrześcijaństwo, teozofia, mistycyzm

\section{Christianity, Mysticism, Infidelity: Ivan Grozev and Nikolay Raynov}

This article follows the personal and artistic relations between two famous Bulgarian poets and mystics, Ivan Grozev and Nikolay Raynov. Before 1944, the lives of both passed under the common sign of Orthodox Christianity, spiritualism, Theosophy, and Freemasonry. A separation took place after 1944, when Raynov rejected all forms of religiosity. At first, their relationship was good, but later it came into sharp conflict. The first words of criticism were spoken by Grozev, concerning Raynov's translation of Thus Spoke Zarathustra by Nietzsche. The further polemics, on the one hand, had a significant impact on some of the intellectual elite in Bulgaria; on the other hand, they illustrate the changing attitude of both writers to religiosity. The source material is archives, memoirs and autobiographies, which reveal the dialogicality in Bulgarian literature in the first half of the 20th century.

Keywords: Ivan Grozev, Nikolay Raynov, Christianity, Theosophy, mysticism 


\section{Notka o autorce}

Elena Azmanowa-Rudarska (Елена Азманова-Рударска) (eazmanova@abv. bg) - doktor w zakresie literatury bułgarskiej, adiunkt na Wydziale Filologicznym Południowo-Zachodniego Uniwersytetu im. Neofita Rylskiego w Błagojewgradzie. Autorka książek: Мемоаристичните творби след Освобождението - фигури на автора (2010), Ритуалното слово в българската лирика след Освобождението (2013), Народничеството в българската литература. Критически ракурси, текстове, учебни материали (2014), Иван Грозев в българската литература. Социални, политически, исторически и религиозно-мистични контексти, полемики и диалози (2018). Zainteresowania badawcze: literaturoznawstwo, historia literatury, religia, mistycyzm, problemy społeczne i kulturowe.

Elena Azmanova-Rudarska (eazmanova@abv.bg) - PhD in Bulgarian Literature, Chief Assistant at the Faculty of Philology, Department of Literature, Neofit Rilski South-West University in Blagoevgrad. Author of the books: Meмоаристичните творби след Освобождението - фигури на автора [Memoir Works After the Bulgarian Liberation - Figures of the Author, 2010], Ритуалното слово в българската лирика след Освобождението [The Ritual Words in Bulgarian Lyrics after Bulgarian Liberation, 2013], Народничеството в българската литература. Критически ракурси, текстове, учебни материали [Populism in Bulgarian Literature: Critical Angles, Texts, Educational Materials, 2014], Иван Грозев в българската литература. Социални, политически, исторически и религиозно-мистични контексти, полемики и диалози [Ivan Grozev in Bulgarian Literature: Social, Political, Historical and Religious-Mystical Contexts, Polemics and Dialogues, 2018]. Research interests: literary studies, history of literature, religion, mysticism, cultural and social issues.

Publication History: Received: 2019-10-23; Accepted: 2019-12-21; Published: 2020-12-31 